\title{
Identifying the resource integration processes of green service
}

Hugo Guyader, Mikael Ottosson, Per Frankelius and Lars Witell

The self-archived postprint version of this journal article is available at Linköping University Institutional Repository (DiVA):

http://urn.kb.se/resolve?urn=urn:nbn:se:liu:diva-154974

N.B.: When citing this work, cite the original publication.

Guyader, H., Ottosson, M., Frankelius, P., Witell, L., (2019), Identifying the resource integration processes of green service, Journal of Service Management. https://doi.org/10.1108/JOSM-12-20170350

Original publication available at:

https://doi.org/10.1108/JOSM-12-2017-0350

Copyright: Emerald

http://www.emeraldinsight.com/ 


\title{
Identifying the Resource Integration Processes of Green Service
}

\author{
Hugo Guyader ${ }^{a *}$, Mikael Ottosson ${ }^{\text {a }}$, Per Frankelius ${ }^{\text {a }}$, and Lars Witell a b
}

\begin{abstract}
Purpose - The present study aims to improve the understanding of green service. In particular, the focus is on identifying homopathic and heteropathic resource integration processes that preserve or increase the resourceness of the natural ecosystem.

Design/methodology/approach - Through an extensive multiple case study involving 10 service providers from diverse sectors based on a substantial number of interviews, detailed accounts of green service are provided.

Findings - Six resource integration processes were identified: reducing, recirculating, recycling, redistributing, reframing, and renewing. While four of these processes are based on homopathic resource integration, both reframing and renewing are based on heteropathic resource integration. While homopathic processes historically constitute a green service by mitigating the impact of consumption on the environment, heteropathic resource integration increases the resourceness of the natural ecosystem through emergent processes and the (re)creation of natural resources.
\end{abstract}

Research limitations/implications - The present study breaks away from the paradigm that "green service" is about reducing the negative environmental impact of existing services, towards providing green service that expands biological diversity and other natural resources.

Originality/value - Transformative service research on environmental sustainability is still in its infancy. The present study contributes through conceptualizing green service, redefining existing resource integration processes (reducing, recirculating, recycling), and identifying new resource integration processes (redistributing, reframing, renewing).

Keywords - Green Service; Resource Integration; Sustainability.

\footnotetext{
${ }^{\text {a }}$ Department of Management and Engineering, Linköping University, Sweden.

${ }^{\mathrm{b}}$ CTF, Service Research Center, Karlstad University, Sweden.

* Corresponding author: hugo.guyader@liu.se, +46 732707759.
} 


\section{INTRODUCTION}

What constitutes green service? More and more organizations are trying to reduce the impact of service provision realized at the expense of the Earth's ecosystem. Despite greener services, the Earth overshoot day (the date on which more resources are consumed than what our natural ecosystem can renew each year) comes earlier each year. ${ }^{1}$ Service provision has a large environmental impact as service sectors dominate the world's economies, but it also has great potential for improving the resource efficiency of the utilization of goods (e.g., Van der Zwan and Bhamra, 2003). Gummesson (1993) introduced the notion of "green service quality" and further emphasized "[...] that services have just as much impact on the environment as goods" (Gummesson, 2000, p. 122). Besides, "greening" service firms and their value propositions should be pursued while providing excellent customer experiences (Graedel, 2003; Grove et al., 1996).

In line with this, transformative service research (TSR) investigates the relationship between service and well-being (Anderson and Ostrom, 2015) with a focus on creating "uplifting changes" aimed at improving the lives of individuals, communities, society, and the natural ecosystem (Anderson et al., 2013; Ostrom et al., 2010)-i.e. uplifting changes not only for consumers, but for the environment as well. Professor Rajiv Sinha commented on the prominent role of new technology in services "increasingly being offered as eco-friendly solutions for environmental problems," but remarked that most research "has been on integrating services into production and consumption decisions to reduce their environmental impact" (Ostrom et al., 2010, p. 11, emphasis added). Similarly, Ostrom et al. (2015, p. 141) pointed to the pressing issues of redesigning services to "protect the environment" and incentivizing customers and employees "to take on roles that reduce a service's negative environmental impact". In other words, although Laurel Anderson emphasized that TSR should examine the "social and ecological consequences and benefits of services offerings" (Ostrom et al., 2010, p. 10, emphasis added), TSR has focused on reducing the negative effects rather than improving the positive effects on the ecosystem for a sustainable future. The authors address this shortcoming in TSR by conceptualizing of green service and its effect on the environment.

There is scarce research on service and sustainability (cf. Anderson et al., 2013; Ostrom et al., 2015). Only a few pioneering service research studies have examined how service provision can reduce environmental impacts of consumption (Enquist et al., 2007; Graedel, 2003; Grove et al., 1996; Gummesson, 1994; Shirahada and Fisk, 2013; Van der Zwan and Bhamra, 2003; Wolfson et al., 2010). The research gaps concerning the environmental aspect of TSR and what green service means highlights the need for further theoretical and conceptual development. In this research, we define green service as service provision aimed at improving the well-being of the natural ecosystem in order "to better the quality of life of present and future generations" (Ostrom et al., 2010, p. 9). ${ }^{2}$ That is, green

\footnotetext{
1 overshootday.org

${ }^{2}$ The third TSR sub-area regards "delivering service in a sustainable manner (i.e., one that preserves health, society, and the environment)" (Ostrom et al., 2010, p. 9)
} 
service is not only service provision focused on satisfying customer needs (while reducing the environmental impact of consumption), but also focused on improving environmental benefits. In a time when natural resources risk becoming depleted, green service increases the resourceness of the natural ecosystem to preserve humanity. This is in line with considering that "the ecosystem entity entails a system of systems of both humans and nature. This broad level consumer entity is included given the importance of recognizing the impact that service entities can have on the natural environment and, by extension, all people" (Anderson et al., 2013, p. 1206). However, service research has remained rather vague in the conceptualization of green service - in other words, "there is no definite understanding of what is green" (cf. Cocca and Ganz, 2015, p. 181). ${ }^{3}$

In this paper, the authors revisit the conceptualization of green service through theory on resource integration by considering two instances in particular: homopathic and heteropathic resource integration (Peters, 2016). First, homopathic resource integration concerns processes resulting in the summation of properties present in each input resource. Second, heteropathic resource integration concerns processes based on emergent relations between resources that result in new and unique properties. Could the one-sided focus on homopathic resource integration processes thus far have hindered further conceptual development, whereas heteropathic processes would be able to further realize green service in light of TSR?

The present study argues that service research has historically focused extensively on economic profitability, and more recently on social profitability, but that TSR has not provided any detailed conceptualization of green service (i.e., improving the well-being of the natural ecosystem). In the present paper, TSR is integrated (cf. MacInnis, 2011) with theory on resource integration to conceptualize green service as not only limited to service provision minimizing environmental impacts, but also as resource integration processes providing environmental benefits. That is, different processes of resource integration are distinguished based on their characteristics and their environmental effects. Through an extensive multiple case study involving 10 service providers, six resource integration processes are specified: four based on homopathic (reducing, recirculating, recycling, and redistributing resources), and two based on heteropathic resource integration processes (reframing and renewing resources).

This study makes several contributions to service research. First, it offers a new conceptualization of green service, based on resource integration. Second, it shows that green service can go beyond reducing the use of resources towards resource integration processes that provide positive benefits to the environment — such as reframing and renewing. Third, further light is shed on homopathic and heteropathic resource integration by empirically investigating these processes and emphasizing new insights for TSR. Finally, the study provides guidelines that can help managers further understand and use the concept of green service.

\footnotetext{
${ }^{3}$ Green service has been alluded to as "green efforts" (Grove et al., 1996), "sustainability thinking" (Enquist et al., 2007), "the whole green thing" (Chun and Giebelhausen, 2012), "sustainability initiatives" (Lacoste, 2016), or "green activities" (Hsiao et al., 2018).
} 


\section{THEORETICAL BACKGROUND}

To better understand green service in light of TSR - i.e. not only "doing the same with less", but also "doing more with less" - it is necessary to pay close attention to how resources are consumed, acted on, transformed, depleted and integrated. The next section concerns how green service can be managed by applying a resource integration perspective. Homopathic and heteropathic resource integration are then discussed, while a final section on resource integration for green service wraps up the theoretical background.

\section{Resource integration}

Previous research on the role of resource integration processes has viewed these "deeds, processes, and performances" (Vargo and Lusch 2004, p. 2) as central to value co-creation (Edvardsson et al., 2014; Gummesson and Mele, 2010; Kleinaltenkamp et al., 2012; Lusch and Vargo, 2014; Peters et al., 2014). Resources play a key role linked to diverse actors' interactions and value co-creation activities, and they have been conceptualized differently in various theoretical streams (including the resource-based view of the firm and servicedominant logic), with regard to how they are acquired, managed, and exchanged in order to achieve a competitive advantage. Examples include resources inside or outside a focal firm (Day, 1994); tangible or intangible resources (Campbell et al., 2013); resources used during manufacturing or during consumption (Grönroos and Voima, 2013); market-facing or nonmarket-facing resources (Lusch and Vargo, 2014); and the distinction between operand resources, such as raw manufacturing materials that require some action to be performed on them, and operant resources, such as knowledge and skills (Lusch and Vargo, 2014). Most importantly, operant resources include human action, emphasizing the role of customers (and employees) using their knowledge and skills to cocreate value (Gummesson and Mele, 2010; Lusch and Vargo, 2014; Payne et al., 2008; Russo-Spena and Mele, 2012).

Pioneering research on resource integration has influenced the conceptualization of 'resourceness' or 'resourceship', which suggests that "resources are not, they become" realized resources when potential resources are acted on (Penrose, 1959; Lusch and Vargo, 2014; Zimmerman, 1951). In other words, it is pointless to have resources without using them (or being able to use them). "The usefulness of any particular potential resource from one source is moderated by the availability of other potential resources from the other sources, the removal of resistances to resource utilization, and the beneficiary's ability to integrate them" (Vargo and Lusch, 2011, p. 184). Therefore, through diverse actions and interactions, humans cocreate value using resources they can access to improve their system viability (Lusch and Vargo, 2014; Mele et al., 2010; Russo-Spena and Mele, 2012). The corollary is that resources become un-resources when they are no longer utilized in value-creating processes (Löbler, 2013; Peters et al., 2014).

Resource integration provides the means for the development of competences used in service provision, both for the actors (resource integrators) themselves and for others (Lusch and Vargo, 2014). That is, resource integration also creates new potential resources for further value co-creation. For instance, resources are integrated (such as cows, a farmer's knowledge and equipment) to create new resources (milk and meat), which are further integrated to create new resources (butter, cheese, yogurt and steak). Resource integration is constituted by a 
continuous "series of activities" (Payne et al., 2008), or, more broadly, the integrative processes of interacting, collaborating or cooperating, and experiencing between actors in a service ecosystem (Edvardsson et al., 2014; Kleinaltenkamp et al., 2012). Within a service ecosystem, resource integrators share the same purpose of maximizing value creation through the best matching of resources, aims, and processes in a way that "resources become valuable when they are matched and positioned through a resource-based value creation network" (Gummesson and Mele, 2010, p. 193).

This paper views resource integration from an interaction-based dynamics approach, but also from an 'emergence' perspective. Emergence is creating a unique entity through the interactive combination of other different entities that do not contain the resulting characteristics "where new dispositional properties emerge from the interaction of resources" (Peters et al., 2014, p. 255). In this respect, Peters (2016) distinguished two instances of resource integration based on the processes of summation (i.e. homopathic resource integration) and emergence (i.e. heteropathic resource integration).

\section{Homopathic and heteropathic resource integration}

Peters (2016) argued that all resource integration processes are based on dynamic interactions, but not all interactions lead to emergent effects. In line with this, she further distinguished instances of homopathic and heteropathic resource integration, respectively without and with emergent effects. First of all (and most basically), homopathic resource integration is based on the concept of summation: the result (or output) corresponds to the sum of the effects from each of the 'base' (or input) resources. For instance, the nutritional benefits of a vegetable salad can be deduced from the aggregation of its ingredients' nutritional benefits.

Heteropathic resource integration is characterized by emergent properties that are new (i.e., "neither reducible to nor determined by the attributes of their base resources", p. 3003), but "nonetheless supervenient (dependent) upon their lower-level base resources in both time and space" (p. 3001). Let us illustrate these two resource integration processes with a focus on natural resources by considering a transportation firm aiming to reduce the environmental impact of its operations that directly or indirectly deplete natural resources (e.g., vehicles' fossil emissions impact air pollution, fuel consumption impacts oil depletion and water pollution). This firm applies a homopathic resource integration process to create environmental benefits, in this case by reducing the firm's negative influence on the environment. However, natural resources need to be preserved, but also maintained in a sustainable fashion for future service-for-service exchanges and value creation (Lusch and Vargo, 2014). By investing in biogas-fueled trucks, the transportation firm is not only reducing its own environmental footprint but also increasing the demand for the production of renewable biogas, which stimulates organic waste collection and sorting, as well as the additional creation of biofertilizer (used by local farms) - in line with the circular economy paradigm aiming to cut waste and shorten distribution channels. To sum up, "heteropathic resource integration literally increases resourceness" (p. 3005), which enhances the potential for value co-creation; while in contrast the homopathic process does not create any new resource properties and thus constrains value appraisal. 


\section{Resource integration for green service}

The identification of resource integration processes for green service was initiated in service research through the investigation of environmental resource efficiency activities. In their research, Grove et al. (1996) organized "green efforts" to become more environmentally committed through the "three Rs" hierarchy of waste management: reducing, reusing, and recycling. Much later, the same group of researchers introduced a fourth $\mathrm{R}$, renewing, at the Frontiers in Service conference (Patricio, Fisk, and Grove, 2009). Rosenbaum and Wong (2015) applied a similar waste management framework to the hospitality industry, measuring renewing as "obtaining some energy from solar panels". Notwithstanding, this relates to reducing rather than renewing resources, since it concerns "[...] reworking or re-engineering service processes to reduce their impact on the environment" (Grove et al., 1996, p. 57). They also add reminding as a specific activity in the hospitality sector, measured as when guests are reminded about the hotel's green marketing programs (Rosenbaum and Wong, 2015).

The three Rs constitute a framework to protect the environment from the negative impacts of service provision. First, reducing means conserving resources by reducing excess or by re-engineering service processes for resource efficiency. This often means providing the same functions while utilizing less resources. Previous research on eco-efficient services (EES; e.g., Bartolomeo et al., 2003; Meijkamp, 1998; Van der Zwan and Bhamra, 2003) and sustainable product service systems (PSS; Mont, 2002; Roy, 2000) ${ }^{4}$ has argued for reducing the use of natural resources through 'product-based services' that extend the lives of existing products (e.g., maintenance, revalorization services). The concept of 'green logistics' (Isaksson and Huge-Brodin, 2013) aims to reduce the environmental impact of logistical processes (such as delivery services) through resource efficiency in a network of suppliers and customers in the supply chain, such as combining transport modes, purchasing in bulk, using eco-friendly fleet and fuel, energy consulting and maintenance services, raising endcustomers' awareness, redesigning products and packaging eco-efficiently, and replacing products with service provision and technology (Chan et al., 2016; Cocca and Ganz, 2015; Enquist et al., 2007; Hsiao et al., 2018; Isaksson and Huge-Brodin, 2013; Lacoste, 2016; Wolfson et al., 2011; Wong et al., 2013; Zhang et al., 2012). Several authors have distinguished between core green service provided by firms themselves and green service supporting other firms in the supply chain (Bartolomeo et al., 2003; Cocca and Ganz, 2015; Hsiao et al., 2018; Isaksson and Huge-Brodin, 2013; Lacoste, 2016; Wong et al., 2013).

Moreover, much is known about "green marketing programs" in the hospitality industry (Rosenbaum and Wong, 2015) where resource efficiency is achieved by reengineering service processes to reduce costs and environmental impact (e.g., energy-efficient light bulbs, renewable energy from solar panels, reduced linen services, waste recycling, and training employees to conserve energy and reduce pollution), and also by involving consumers through self-sorting waste, using fewer plastic bags, asking restaurant patrons to use recyclable/reusable items, or reminding hotel guests to close windows, turn off lights, and consider waiting for fresh laundry (Chun and Giebelhausen, 2012; Hsiao et al., 2018; Rosenbaum and Wong, 2015; Zhang et al., 2012).

\footnotetext{
4 The term "product" in the PSS literature refers to tangible goods.
} 
Second, reusing simply means using discarded and second-hand items (or some of their parts) again by repairing or refurbishing them. In the EES and PSS literature, 'useoriented services' resources can be reused through substitutes for product ownership in the form of pooling, renting, or leasing (such as car rentals or ridesharing), and 'result-oriented services' that offer the benefits of product ownership through intangible solutions, electronicsubstitution and information-based services - such as hairdressing, laundromats, energy systems, advice, and consultancy (e.g., Meijkamp, 1998; Mont, 2002; Van der Zwan and Bhamra, 2003).

Third, recycling is the process of collecting and demanufacturing waste back into resources for industrial remanufacturing (e.g. Grove et al., 1996; Rosenbaum and Wong, 2015). For instance, a product is considered to be waste when there is no value left in the item as is. This is different from reusing products by repairing them, although both processes take place after consumption (Gummesson, 1994). As such, recycling reduces waste through various sub-processes (reclaiming, sorting, processing, converting, etc.), which in themselves consume resources, meaning that the recycling approach of transforming waste back into raw material might prove to be a non-efficient resource integration process for green service.

Table 1 shows that most green service research has focused on conceptual contributions with empirical illustrations involving a limited use of case study and survey research. Green service is supported by the dematerialized processes of service provision and builds on a diverse set of resource integration processes (reducing, reusing, recycling). Further research is needed into the resource integration processes in order to better conceptualize how resources are created, used, and discarded (Edvardsson et al., 2014; Gummesson and Mele, 2010; Kleinaltenkamp et al., 2012; Peters et al., 2014). This paper takes the perspective of a focal firm's activities (including its interaction with supply chain partners, employees, and consumers) and the impact on the environment in order to develop the understanding of green service. While previous service research has focused on instances of homopathic resource integration, the present study extends the conceptualization of green service towards heteropathic resource integration, enabling green service to be conceptualized in the tradition of TSR (Anderson and Ostrom, 2015).

- Insert Table 1 about here -

\section{METHOD}

\section{Case study data collection}

As resource integration within multi-actor networks is a complex process requiring in-depth understanding of underlying green service characteristics, we adopted a qualitative approach in this study (Eisenhardt and Graebner, 2007; Mele et al., 2010). The multiple case study included green service in 10 organizations (Yin, 2018), representing diverse sectors: transportation, consumer goods, and industrial services. The rationale for the multiple case method was that it allows the analysis of issues from different standpoints and is considered to be an effective means of gaining new knowledge about specific phenomena (Eisenhardt and Graebner, 2007; Yin, 2018). Case studies are especially strong for theory development (Mele et al., 2010; Voss et al., 2002). Specifically, multiple case analysis was expected to 
facilitate in-depth understanding of the contextual factors and underlying processes influencing resource integration processes, and thereby develop a refined and extended conceptualization of green service based on homopathic and heteropathic resource integration processes. All of the case studies were performed in Sweden, a country that has a strong reputation for sustainable production and consumption in Europe. An overview of the cases is available in Table 2.

- Insert Table 2 about here -

Cases were selected from a pool of organizations taking part in ongoing research projects on green service. The chosen organizations had to exhibit an interest in increasing their focus on green service, which was manifested by, for example, green service being on the organization's strategic agenda or being singled out as a key area for further growth. In addition, the organizations had to provide access to key informants, site visits, documentation, and other types of data. The multiple cases included in the sample were based on theoretical sampling where the authors could see variability in the services provided (Gibbert et al., 2008; Voss et al., 2002). Application of the selection criteria resulted in the sample of 10 firms that collectively represent a range of industries, products, and services, as described in Table 2. All firms are established and have infused green service in their value propositions to create a competitive advantage.

The primary data collection method was semi-structured interviews that were conducted with the aid an interview guide (Kvale, 1996). The interview guide provided a structure for the interviews and its questions were relatively open-ended to avoid introducing bias (Gibbert et al., 2008). When necessary, the interviewing researchers asked follow-up questions to allow further exploration of details on key issues to better understand green resource integration. Data were mainly collected over several years (2013-2017), and the interviews generally lasted for 1-2 hours and were often combined with a site visit or a demonstration of the green service. The majority of the interviews were recorded and transcribed. A few interviews were conducted at industrial sites, which precluded them from being recorded; in those instances, two researchers participated in the interviews, taking detailed notes that were subsequently merged. The respondents represented several distinct organizational positions, such as service manager, business development manager, environmental manager, $\mathrm{CEO}$, and marketing manager, as well as customer representatives. This range, including respondents from several levels and networks, enabled data triangulation within the individual cases (cf. Yin, 2018).

\section{Data analysis}

In order to identify key resource integration processes, the data analysis process first identified important meanings and themes in the empirical material. Interview transcripts and notes were coded for content based on resource integration processes. The identified meanings were later read in relation to one another, enabling patterns in the overall material to be discerned (Strauss and Corbin, 1990; Yin, 2018). This data analysis method enabled the researchers to detect similarities in the cases within the different organizations. In the second step, the researchers categorized the identified patterns in accordance with the overall focus 
on green service. Hence, within-case analyses were first performed and later merged into a cross-case analysis (Eisenhardt and Graebner, 2007).

The content analysis was based on the theoretical framework for green service. First, we coded for the type of resource integration process based on existing frameworks (Grove et al., 1996; Rosenbaum and Wong, 2015). Second, we coded for operand and operant resources mobilized in the resource integration process (Lusch and Vargo, 2014). Third, we coded for the strategic orientation of the green service, either core services or support services (Cocca and Ganz, 2015; Isaksson and Huge-Brodin, 2013). Fourth, we coded the types of resource integration processes, distinguishing between homopathic and heteropathic (Peters, 2016). A final sequence of iterations, switching sequentially between empirical results and theoretical concepts (Dubois and Gadde, 2002), generated and developed a redefined understanding of existing resource integration processes and identified new resource integration processes.

\section{RESULTS}

This section presents the green resource integration processes identified in the multiple case study; namely, reducing, recirculating, recycling, redistributing, reframing, and renewing. Table 3 provides an overview of the analysis of the 10 cases.

- Insert Table 3 about here -

\section{Reducing}

By introducing "clean tech" into existing products, the same production process can be used with fewer resources (operand resources) needed. Valmet, a manufacturer of pulp and paper machines, integrated a new technology (OptiCycle) into its paper machines to reduce water consumption by 30 percent. The company's marketing manager described the situation as follows: "We have a machine now that is using less energy, less water and less material, but you are making a better product with it, so we've come up with a concept that is addressing all those things for the customer." The new technology is an operant resource for Valmet customers that can be used in two ways: it can either be used in new machines or provided as a service to rebuild existing machines. In such a business, where the product life cycle is rather long (up to 50 years for paper machines), green service can prolong the lifecycle by increasing the productivity and resource efficiency of the machines. The clean tech only uses 2.5 percent of the resources needed for the least environmentally friendly production technology in use.

Volvo's driver training program is built on the idea that having clean tech in its vehicles is not enough; there is also a need to improve how the vehicles (operand resources) are driven. The idea is to improve the drivers' knowledge and skills (operant resource) of how to operate the vehicles more ecologically (i.e., reducing fuel consumption) and economically (improving productivity). A sales manager at Volvo described it as follows: "The trainer first lets the truck drivers drive, without commenting on their driving. Afterwards he holds a class and finally he lets them drive once again. However, this time he comments on everything they do-both right and wrong." This green service is called "Eco-Operator" and reduces fuel consumption by up to 20 percent, depending on the initial performance of the driver. 


\section{Recirculating}

The Red Cross second-hand shop illustrates how discarded items such as clothes or furniture (operand resources) can be recirculated from where they are no longer wanted to consumers who need them. Such second-hand shops exist in several different ways: either items can be sold at a low price to individuals in need or they can be sold in more exclusive 'vintage' shops, where the store focuses on specific items or brands. In the case of the Red Cross, donated items are sold at a low price to new owners, so that their time of use can be extended. Such second-hand marketplaces require other actors' involvement: the donors must change their behavior from throwing used items away to saving them and giving them to charity. One board member described this as "the brand must be aligned with green and social initiatives". The Red Cross, as a service provider, runs a second-hand shop in an environmentally, socially, and economically sustainable manner. Based on the regional market in which this second-hand shop is situated, there are a growing number of such shops with several market actors, suggesting that services are based on the green resource integration process of recirculating.

\section{Recycling}

Econova uses resources that cannot be reused (operand resources no longer valuable for ecosystem actors, or 'un-resources') in their current state and converts them into raw materials that can be used in new products (also called downcycling or demanufacturing). Econova processes the sludge (organic waste that would otherwise be burnt) from pulp and paper mills, extracts minerals and other nutrients (operand resources) and adds other materials (operand resources) to create nutritious soil for gardens. Econova's integration of biological knowledge and technological skills (operant resources) does not require other actors in the ecosystem to change their processes: the pulp and paper mill continues producing sludge as usual, and the consumers buy and use soil as usual. The business manager at Econova stated: "The more integrated our way of working can be, the more we can create a greener economy and a better future. Our idea is that nature should do the work for us-composing and closing the biological cycle."

Similarly, Tekniska Verken, a municipally owned energy firm, recycles organic waste (un-resources) into biogas (operand resources). It collects biodegradable food from households, who have to sort their leftovers into specific "green bags". Household members are actors who play an active part (operant resources) in the resource integration of waste. By improving the performance and technical efficiency of downcycling (operant resources), Tekniska Verken recycles waste into biogas (a renewable energy) and biofertilizer (an ecofriendly product) at its production facilities. Today, biogas accounts for 6 percent of the total vehicle fuel consumption (i.e., a further resource integration process, clean tech) in the region (e.g., city buses and municipal service vehicles are fueled by biogas) so the air in the center of the city is much cleaner and almost free of dust, sulfur, and nitrogen compounds due to the substitution of diesel vehicles for biogas vehicles. Furthermore, Tekniska Verken has become a pioneer in the biogas market and presents biogas as an important part of its vision to create "The most resource efficient region in the world". 


\section{Redistributing}

GoMore is an online platform that facilitates car rentals between consumers, which makes it possible to make use of underutilized vehicles. When the car is idle (operand resource), the owner can rent it to other drivers (operant resources). GoMore enables the redistribution of tangible products (privately owned vehicles) through peer-to-peer (P2P) exchange of products, although there is no transfer of ownership between platform users. The platform technology (operant resource) enables GoMore to leverage its customers' resources (vehicles already on the market) that are outside the firm. Redistributing instead of producing new resources (vehicles) is better for the environment. GoMore's value proposition is a "flexible, affordable and green transportation" (junior manager), with a business model based on a commission for each P2P exchange. Customers of such P2P platforms rent products in the same commercial exchange as they would from traditional firms.

Similarly, Skjutsgruppen is a non-profit service that enables individuals to exchange P2P services focused on ridesharing. Users of the sharing platform can share their journey with others traveling in the same direction (travelers are potential resources that become valuable when integrated through interaction), whether by car, by bus, or even by boat. Since the start, the founder's vision has been for Skjutsgruppen to reduce the number of individuals traveling alone and thereby their environmental impact (traffic congestion and $\mathrm{CO}_{2}$ emissions), by making it easier to redistribute underutilized resources such as space in the vehicle (operand resource that needs to be filled by someone; that is, by an operand resource themselves). Skjutsgruppen's statutes state that the organization should "promote environmentally friendly forms of travel with a focus on joint-traveling, such as ridesharing, or public transportation", which is why Skjutsgruppen defines ridesharing as "all forms of common environmentally friendly travel". The founder has stated that "the ideal situation would be to use trams, trains, etc. so we can't say we're super-green with cars. It's greener, not the greenest solution. " Ridesharing is an example of a P2P service exchange in which intangible resources (space) are redistributed, for the duration of a journey, so Skjutsgruppen reduces the environmental impact of traveling by reducing the number of empty seats.

\section{Reframing}

Reframing involves giving a new purpose to an existing resource that is considered waste; in other words, an un-resource with a lack of potential for value co-creation. In the case of Dalhalla, an old limestone quarry was turned into a venue for music festivals. The firm ceased use of its limestone quarry, leaving a gigantic hole in the bedrock after centuries of digging. An entrepreneur had the idea of creating a new kind of summer arena for opera (operand resource to be used by musicians) in place of the quarry: "As soon as I saw place, I knew: this is the place for an international opera festival. I christened it Dalhalla, thinking of Wagner." Based on her 20 years of experience as opera producer for Swedish public radio, the entrepreneur knew that the acoustic quality of the limestone and the quarry's vertical walls could be put to a better use than as a municipal landfill dump. The waste (40,000 tons of blasted limestone) was used as material to set up the stage. The first concert was held in 1994, and was acclaimed locally and recognized internationally as an opera innovation (e.g., outstanding acoustics independent of electronic amplification, which reduced energy 
consumption) and greener than other arenas. Dalhalla also had a positive effect on the economy in the region. Although it started with opera performances, Dalhalla also hosts pop and rock music concerts with artists such as Scorpions, Neil Young, ZZ Top, and Sting.

\section{Renewing}

MaxTech designs and maintains natural water systems (water reservoirs and lakes) to improve and restore ecosystems and biodiversity, thereby creating new natural resources. Hence, its operations are an example of renewing natural resources. MaxTech invented the "pontoon digger" (or amphibian digger), which is a combination of a carrier and a digger that can "swim in water". That is an operand resource used by MaxTech to provide landscaping services (operant resource) to customers and help them create new wetlands that are important for specific biological species. For instance, MaxTech tailors the size and depth of a pond and initially implements particular floating plants or algae to help a surrounding forest to regenerate. One of its managers described this as follows: "Old-fashioned ditches as parts of bigger water reservoirs have the ability to catch nitrogen and other kinds of material that one wants to stay away from sea areas such as the Baltic Sea." MaxTech not only mitigates the impact of its activities by using efficient machines; its core green service of renewing natural ecosystems is also important for many biological species. For instance, one 2.6-hectare lake was created in order to stimulate the biotope of birds, which help to pollinate plants and maintain sustainable population levels of insects, and also serve as prey later on in another food chain.

Similarly, Pratensis produces flower and plant parcels for new meadows, or to enlarge existing ones in order to renew natural resourceness. Pratensis can offer about 100 different species of meadow plants (operand resources) as well as services and advice (operant resources) to customers. For example, Pratensis selects and combines specific seeds in offerings called 'butterfly mixture' or 'bumblebee mixture', which, when planted in meadows, attract butterflies and bumblebees. Pratensis integrates the client's specific needs (e.g., a city council wishing to increase biodiversity and the overall natural ecosystem viability in its public parks by stimulating pollination with insects) and current resources (such as existing plants) with its own resources (such as cultivated or collected seeds). The green service can be described as restoring and expanding the natural ecosystem, since wild flowers in turn attract butterflies and bees, and provide food and habitats for several other different animal groups. Therefore, Pratensis's services help renew the biosphere.

\section{DISCUSSION}

In this section, the identification of green resource integration processes is discussed, emphasizing the difference between homopathic and heteropathic resource integration. The present study identifies green service via six instances of resource integration processes. This is wider in scope than existing green service research that has focused solely on reducing the impact of green service on the environment. The processes of reducing, reusing and recycling have been extensively studied in previous research (e.g., Grove et al., 1996; Van der Zwan and Bhamra, 2003; Wolfson et al., 2011), while the resource integration processes based on recirculating (i.e., instead of reusing), reframing, redistributing, and renewing provide a fresh 
perspective on green service and a novel contribution to service research. Hence, the paper extends the existing understanding of green service by introducing new types of green service processes.

\section{Green resource integration processes based on homopathic resource integration}

Green service based on homopathic resource integration processes takes place due to the constraints operating in a given social context that aim to maintain an existing service system (Peters et al., 2014). Reducing, recirculating, recycling, and redistributing are examples of homopathic resource integration that are based on a summative effect of the different resources. Such green resource integration processes preserve the existing service system or create new service systems based on resources that consumers have previously considered unresources.

First, the process of reducing involves altering the manufacturing of the tangible products, the service provision or their utilization. In a nutshell, reducing is doing the same thing with less resources. For instance, Volvo's 'eco-operator' training educates its B2B clients' drivers to reduce fuel consumption and helps them mitigate the environmental impact of their operations and, most importantly, save costs. The green resource integration process is not the core business of these firms (e.g., Volvo is a vehicle manufacturer and not a driving school), which limits its contribution to providing green service in support of other firms. Reducing is a homopathic resource integration process where the sum of each input resource's effects (various technologies, for example) is found in the resulting effects.

Second, recirculating is the resource integration process that extends the utilization of existing resources. In previous research, this resource integration process was conceptualized as "reusing" (e.g., Grove et al. 1996), i.e. using second-hand items. The present paper argues that this terminology anchored in the waste management framework (reduce, reuse, recycle) lacks conceptual boundaries. This process can evidently be achieved within a firm, or as a servitization strategy (e.g., providing rental services instead of selling products), but as a green resource integration process it is particularly interesting when there is a change of ownership, such as a new actor making further use of existing resources. For instance, second-hand markets (both online ones like craigslist.org and offline ones like charity thrift stores) support the recirculation of durable goods that are no longer new and, more importantly, not desired by their owners, so they can be sold to new users who want or need them. That is, such discarded or unwanted items are not considered as waste, but as potential resources for further resource integration processes. Recirculating might be the core business of the firms, but like the process of reducing, the actual environmental savings are realized by other actors in the service ecosystem. Ultimately, used tangible goods changing owners is a homopathic resource integration process as no unique property is identified in the resultant effects.

Third, the recycling process of resource integration is different from recirculating in that it focuses on un-resources considered waste and no longer useful. (On the contrary, waste is associated with pollution and value destruction.) Similarly, for households using food scraps to produce compost and to fertilize soil, recycling firms have recognized waste as a potential resource and have specialized in extracting minerals and biogases from food leftovers or industrial sludge, for instance. In other words, technology (i.e., human skills and 
knowledge) is applied to existing resources (waste) to transform them into other resources (raw material). As the properties found in organic fertilizer reduce properties already found in the organic waste used as input, recycling is a homopathic resource integration process.

Fourth, redistributing is a resource integration process that increases the utilization of existing tangible and intangible resources. As such, redistribution is the circulation and shared usage of resources, from one actor who possesses underutilized resources to another actor who can make use of them, but without any change in ownership (access to resources is temporal). The collaborative consumption phenomena enabled by online platforms facilitate the P2P exchange of goods and services (through rental or borrowing), which unlocks value in using existing resources. Organizations such as GoMore and Skjutsgruppen help other actors to provide green service. With widespread technological improvements (the Internet, smartphones, etc.), redistributing is the fastest growing green service. This supports the view that collaborative consumption and product-sharing services have a great potential to provide environmental benefits (Johnson et al., 1998; Schrader, 1999). However, previous research has conceptualized such redistributing as "reusing", whereas the present study distinguishes redistributing from recirculating since the underlying mechanisms are quite different. In contrast to recirculating, there is no change in ownership when redistributing resources through collaborative consumption. As such, it is a new resource integration process for green service.

Green service based on homopathic resource integration might restrict or create constraints in a market, resulting in a stifling resourceness (Peters, 2016). It enables consumers to keep their behavior and support service systems based on the use of existing resources. The summative effect of homopathic resource integration makes it easier for firms to implement such processes in their businesses. Green service based on homopathic resource integration provides a necessary reduction in the negative effects of service provision on the environment but is not sufficient to create a sustainable service sector.

\section{Green resource integration processes based on heteropathic resource integration}

Reframing and renewing are instances of heteropathic resource integration (Peters, 2016) and can be considered essential for green service provision. Since heteropathic resource integration provides benefits not only to the consumer but also to the service system itself (Peters, 2016), it increases resourceness, which can replenish the natural ecosystem and delay the Earth overshoot day. However, green service based on heteropathic resource integration often fails to provide a competitive advantage or become profitable for the service provider and, consequently, no long-term effect on the ecosystem's well-being. This situation is more apparent for renewing, while several businesses have been successful in creating a sustainable business model based on reframing. This is due to the appraisal of value by the consumer (Grönroos and Voima, 2013); if the consumer cannot identify the value-in-use and be willing to pay for the emergent effects on the environment, such a green service will not succeed in the market.

Reframing involves taking a new perspective on waste and envisioning alternative uses for such resources. Instead of downcycling or recycling waste into raw material (homopathic resource integration), reframing concerns a creative resource integration process 
that involves finding new ways to use existing, tangible, but unwanted resources. In the Dalhalla case, an abandoned quarry was turned into an opera service experience. In a similar way, other cultural activities such as sculpting, jewelry-making, or other forms of craftwork are reframing processes. The same resource integration is used in day-to-day life, where old tires are turned into swings at the playground and old industrial items are turned into designer furniture. Reframing enables a resource-efficient way of taking care of waste and can help society find alternative uses for resources. By giving a new purpose to existing resources, reframing is distinct from recirculating (where resources are reused as such).

Renewing means replenishing natural resources that have been depleted through replanting or restoring the Earth's ecosystem, with the objective of actually renewing them. Previous research has focused on reducing rather than increasing the volume of resources used in service provision (e.g. Grove et al., 1996; Rosenbaum and Wong, 2015; Van der Zwan and Bhamra, 2003; Wolfson et al. 2011). As an instance of heteropathic resource integration, renewing enables resource integrators to interact and appraise resources to not only create value for themselves (e.g., an airport landscape), but also for other actors in the ecosystem (e.g., increased biodiversity, new meadows). Thus, renewing is the most beneficial process for green service because its distinctive emergent properties enable value appraisal and co-creation (Lusch and Vargo, 2014; Peters, 2016).

Although the present study has emphasized the need for heteropathic resource integration processes, these processes may not be entirely positive for the environment. It is conceivable that the emergent properties in such processes could have negative effects on the environment (DeGregori, 1987). As an example, reframing a resource can lead to consumers being exposed to toxic substances, or the creation of a new meadow could aid the spread of a new plant that changes the balance in local natural ecosystems. Green service based on heteropathic resource integration processes can help create the prerequisites for increasing natural resources, but it is equally true that there is a risk of negatively, unintentionally, impacting on the natural ecosystem.

\section{Theoretical implications}

The present study has addressed green service by challenging the present focus of service research on solely reducing the use of resources. Through an empirical study of 10 green service cases, this study resonates with service research focusing on the resource integration processes of reducing, recirculating, and recycling. In particular, the present study makes three important contributions.

First, the research revitalizes the concept of green service, which has received scarce attention in service research in general and TSR in particular. Since the introduction of green service by Gummesson (1993), and the conceptual development based on the three Rs by Grove et al. (1996), much of the academic debate concerning green service has taken place at conferences, with few peer-reviewed publications in scholarly journals. To spark the discussion on sustainability in TSR, this study shifts the focus from the negative effects of service provision towards the benefits of green service in improving the well-being of consumers, businesses, and the ecosystem (Anderson and Ostrom, 2015; Anderson et al., 2013). 
Second, previous research has focused on the preservation of existing service systems and making better use of existing resources. A different perspective is adopted here, shifting the focus from a minimization perspective towards increasing the ecosystem's resourceness. To enable such a shift in focus, the present research revisited the "three Rs" hierarchy of waste management (Grove et al., 1996) to challenge existing resource integration processes and identify new ones. Six distinct green resource integration processes are detailed: reducing, recirculating, recycling, redistributing, reframing, and renewing. Identifying these processes is important because it improves the conceptual clarity of green service and further develops the understanding of the relationship between service and sustainability. Three new resource integration processes - redistributing, reframing, and renewing - with unique characteristics and mechanisms were identified. Introducing theory on homopathic and heteropathic resource integration processes is a contribution to research on green service, and the emerging characteristics of heteropathic resource integration processes in particular is consistent with the focus in TSR on creating "uplifting changes" (Anderson et al., 2013; Ostrom et al., 2010).

Third, the present study contributes to further conceptual development and application of homopathic and heteropathic resource integration processes (Peters, 2016). The framework developed by Peters (2016) is used to explain the mechanisms of green service. Most service research on green service has emphasized homopathic resource integration (e.g., Grove et al., 1996), but this research argues that many service providers start to adopt heteropathic resource integration processes (Peters, 2016). The emergent process in heteropathic resource integration provides a theoretical explanation of the limits of the present adoption of green service in industry, and shows that reframing and renewing are key resource integration processes. The results emphasize the positive side of heteropathic resource integration, but these processes also have negative sides that can decrease natural resources. Previous studies have not looked at either the positive or the negative sides of green service based on heteropathic resource integration. This framework for green service also explains the difficulties of sustaining green service financially, since it is often not the core service of these firms, or consumers are not willing to pay for the positive effects on the service system.

\section{Managerial and societal implications}

For managers, the conceptualization of green service presented here provides a framework for them to discuss and address the environmental perspective on service provision. This study recognizes the importance of service firms focusing on environmental sustainability when implementing technological improvements and of involving consumers in the value cocreation process. Green service differs with the actor's degree of involvement. To put it another way, green service can require no change whatsoever (e.g., an airline's $\mathrm{CO}_{2}$ compensation program does not affect its customers' travel) or a considerable change in consumer behavior (such as that involved with collaborative consumption).

Not least, this study shows that proactive service firms not only have the option to reduce their negative impact on the environment, but they also have an option to reframe or renew the natural environment to improve resourceness. Being environmentally proactive concerns going further than anticipating customer needs, in also being innovative, and changing markets (Narver et al., 2004). Thus, proactive service firms are initiative-taking, future-oriented, change-inducing, and innovative in order to shape environmentally 
sustainable markets and societies. While some firms have problems including this proactive dimension in their core business model, the option remains to add business services that renew the natural ecosystem. For instance, an airport facility organization can provide meadow seeds to its customers to inspire them and stimulate bee pollination, as in the Pratensis case.

In line with TSR, green service provides uplifting changes in society by improving the environment's resourceness in times where access to basic needs is not guaranteed for all due to the over-consumption of natural resources (cf. the Earth overshoot day). Instead of striving to maximize returns from resource integration (e.g., driving further with the same amount of fuel), service organizations that strive to increase natural resources are taking on a critical role for the well-being of humanity today and future generations. The conceptualization of green service proposed in this paper entails a transformative vision that encourages firms and other actors in society to act towards the betterment of environmental sustainability, rather than reacting passively to regulations by engaging in containment measures that reduce environmental impact - when it is already too late.

\section{Limitations and further research}

As with all empirical research, the present study has certain limitations. Although the inclusion of 10 cases of green service enabled us to explore a new set of resource integration processes, analyzing additional cases might have revealed additional resource integration processes and extended the view of green service. Further research should address green service based on heteropathic resource integration. There is a need to further the understanding of the differences between homopathic and heteropathic resource integration for green service provision. In particular, there is a need to further study sustainable business models for green service based on heteropathic resource integration. Identifying inhibiting market mechanisms for such green service would be beneficial for understanding the successes and failures of green service innovations based on resource integration processes such as reframing and renewing.

\section{REFERENCES}

Anderson, L. and Ostrom, A.L. (2015), "Transformative service research: Advancing our knowledge about service and well-being”, Journal of Service Research, Vol. 18 No. 3, pp. 243-249.

Anderson, L., Ostrom, A.L., Corus, C., Fisk, R.P., Gallan, A.S., Giraldo, M., Mende, M., Rayburn, S.W., Rosenbaum, M.S., Shirahada, K. and Williams, J.D. (2013), "Transformative service research: An agenda for the future", Journal of Business Research, Vol. 66 No. 8, pp. 1203-1210.

Bartolomeo, M., dal Maso, D., de Jong, P., Eder, P., Groenewegen, P., Hopkinson, P., James, P., Nijhuis, L., Örninge, M., Scholl, G., Slob, A. and Zaring, O. (2003), "Eco-efficient producer services - What are they, how do they benefit customers and the environment and how likely are they to develop and be extensively utilised?" Journal of Cleaner Production, Vol. 11 No. 8, pp. 829-837. 
Brodie, R.J. and Gustafsson, A. (2016), "Enhancing theory development in service research", Journal of Service Management, Vol. 27 No. 1, pp. 2-8.

Campbell, N., O’Driscoll, A. and Saren, M. (2013), "Reconceptualizing Resources: A Critique of Service-Dominant Logic”, Journal of Macromarketing, Vol. 33 No. 4, pp. 306-321.

Chan, T.-Y., Wong, C.W.Y., Lai, K.-H., Lun, V.Y.H., Ng, C.T. and Ngai, E.W.T. (2016), "Green service: Construct development and measurement validation", Production and Operations Management, Vol. 25 No. 3, pp. 432-457.

Chun, H.H. and Giebelhausen, M. (2012), "Reversing the green backlash in services: credible competitors help large companies go green", Journal of Service Management, Vol. 23 No. 3, pp. 400-415.

Cocca, S. and Ganz, W. (2015), "Requirements for developing green services", Service Industries Journal, Vol. 35 No. 4, pp. 179-196.

Cook, M. (2014), "Fluid transitions to more sustainable product service systems", Environmental Innovation and Societal Transitions, Vol. 12, pp. 1-13.

Day, G.S. (1994), "The capabilities of market-driven organizations”, Journal of Marketing, Vol. 58 No. 4, pp. 37-52.

De Gregori, T.R. (1987), "Resources are not; they become: An institutional theory", Journal of economic issues, Vol. 21 No. 3, pp. 1241-1263.

Dubois, A. and Gadde, L.E. (2002), "Systematic combining: An abductive approach to case research", Journal of Business Research, Vol. 55 No 7, pp. 553-560.

Edvardsson, B., Kleinaltenkamp, M., Tronvoll, B., McHugh, P. and Windahl, C. (2014), "Institutional logics matter when coordinating resource integration", Marketing Theory, Vol. 14 No.3, pp. 291-309.

Eisenhardt, K.M. and Graebner, M.E. (2007), “Theory building from cases: opportunities and challenges", Academy of Management Journal, Vol. 50 No. 1, pp. 25-32.

Enquist, B., Edvardsson, B. and Sebhatu, S.P. (2007), "Values-based service quality for sustainable business", Managing Service Quality, Vol. 17 No. 4, pp. 385-403.

Gibbert, M., Ruigrok, W. and Wicki, B. (2008), "What passes as a rigorous case study?", Strategic Management Journal, Vol. 29 No. 13, pp. 1465-1474.

Graedel, T.E. (2003), “Greening the service industries”, The Service Industries Journal, Vol. 23 No. 5, pp. 48-64.

Grönroos, C. and Voima, P. (2013), "Critical service logic: Making sense of value creation and co-creation", Journal of the Academy of Marketing Science, Vol. 41 No. 2, pp. 133150 .

Grove, S.J., Fisk, R.P., Pickett, G.M. and Kangun, N. (1996), "Going green in the service sector: Social responsibility issues, implications and implementation", European Journal of Marketing, Vol. 30 No. 5, pp. 56-66.

Gummesson, E. (2000), "Evert Gummesson”, in Fisk, R.P., Grove, S.J. and John, J. (Eds.), Services marketing self-portraits: Introspections, reflections, and glimpses from experts, American Marketing Association, Chicago, IL, pp. 109-132.

Gummesson, E. (1993), “Green service quality”, $3^{\text {rd }}$ Quality in Services Symposium, Karlstad, Sweden, June 1992. 
Gummesson, E. (1994), "Service management: An evaluation and the future", International Journal of Service Industry Management, Vol. 5 No. 1, pp. 77-96.

Gummesson, E. and Mele, C. (2010), "Marketing as value co-creation through network interaction and resource integration", Journal of Business Market Management, Vol 4, No. 4, pp. 181-198.

Heiskanen, E. and Jalas, M. (2003), "Can services lead to radical eco-efficiency improvements? - A review of the debate and evidence", Corporate Social Responsibility and Environmental Management, Vol. 10 No. 4, pp. 186-198.

Hsiao, T.-Y., Chuang, C.-M. and Huang, L. (2018), "The contents, determinants, and strategic procedure for implementing suitable green activities in star hotels", International Journal of Hospitality Management, Vol. 69, pp. 1-13.

Isaksson, K. and Huge-Brodin, M. (2013), "Understanding efficiencies behind logistics service providers' green offerings”, Management Research Review, Vol. 36 No. 3, pp. $216-238$.

Johnson, M., Herrmann, A. and Huber, F. (1998), "Growth through product-sharing services", Journal of Service Research, Vol. 2 No. 1, pp. 167-177.

Kvale, S. (1996), Interviews: An introduction to qualitative research interviewing, Sage, Thousand Oaks, CA.

Kleinaltenkamp, M., Brodie, R.J., Frow, P., Hughes, T. and Peters, L.D. (2012), "Resource integration", Marketing Theory, Vol. 12 No. 2, pp. 201-205.

Lacoste, S. (2016), "Sustainable value co-creation in business networks", Industrial Marketing Management, Vol. 52, pp. 151-162.

Löbler, H. (2013), "Service-dominant networks: An evolution from the service-dominant logic perspective", Journal of Service Management, Vol. 24 No. 4, pp. 420-434.

Lusch, R.F. and Vargo, S.L. (2014), Service-Dominant Logic: Premises, perspectives, possibilities, Cambridge University Press, New York, NY.

MacInnis, D. J. (2011), “A framework for conceptual contributions in marketing”, Journal of Marketing, Vol. 75 No. 4, pp. 136-154.

Meijkamp, R. (1998), “Changing consumer behavior through eco-efficient services: An empirical study on car sharing in the Netherlands", Business Strategy and the Environment, Vol. 7 No. 4, pp. 234-244.

Mele, C., Russo-Spena, T. and Colurcio, M. (2010), "Co-creating value innovation through resource integration", International Journal of Quality and Service Sciences, Vol. 2 No. 1, pp. 60-78.

Mont, O. (2002), "Clarifying the concept of product-service system", Journal of Cleaner Production, Vol. 10 No. 3, pp. 237-245.

Narver, J.C., Slater, S.F. and MacLachlan, D.L. (2004), "Responsive and proactive market orientation and new-product success", Journal of Product Innovation Management, Vol. 21 No. 5, pp. 334-347.

Ostrom, A.L., Parasuraman, A., Bowen, D.E., Patricio, L. and Voss, C.A. (2015), "Service research priorities in a rapidly changing context", Journal of Service Research, Vol. 18 No. 2, pp. 127-159.

Ostrom, A.L., Bitner, M.J., Brown, S.W., Burkhard, K.A., Goul, M., Smith-Daniels, V., Demirkan, H. and Rabinovich, E. (2010), "Moving forward and making a difference: 
Research priorities for the science of service”, Journal of Service Research, Vol. 13 No. 1, pp. 4-36.

Patricio, L., Fisk, R.P. and Grove, S.J. (2009), “'Greenprinting’: Designing service delivery systems for sustainability", $18^{\text {th }}$ Annual Frontiers in Service Conference, Honolulu, HI, October 2009.

Payne, A.F., Storbacka, K. and Frow, P. (2008), "Managing the co-creation of value", Journal of the Academy of Marketing Science, Vol. 36 No. 1, pp. 83-96.

Penrose, E.T. (1959), The theory of the growth of the firm, Oxford University Press, New York, NY.

Peters, L.D., Löbler, H., Brodie, R.J., Breidbach, C.F., Hollebeek, L.D., Smith, S.D., Sörhammar, D., and Varey, R.J. (2014), "Theorizing about resource integration through service-dominant logic”, Marketing Theory, Vol. 14 No. 3, pp. 249-268.

Peters, L.D. (2016), "Heteropathic versus homopathic resource integration and value cocreation in service ecosystems", Journal of Business Research, Vol. 69 No. 8, pp. 29993007.

Rosenbaum, M.S. and Wong, I.A. (2015), "Green marketing programs as strategic initiatives in hospitality”, Journal of Services Marketing, Vol. 29 No. 2, pp. 81-92.

Roy, R. (2000), “Sustainable product-service systems”, Futures, Vol. 32 No. 3-4, pp. 289299.

Russo-Spena, T. and Mele, C. (2012), “"Five Co-s” in innovating: a practice-based view”, Journal of Service Management, Vol. 23 No. 4, pp. 527-553.

Schrader, U. (1999), "Customer acceptance of eco-efficient services: A German perspective", Greener Management International, Vol. 25, No.25, pp. 105-121.

Shirahada, K. and Fisk, R.P. (2011), "Broadening the concept of service: A tripartite value cocreation perspective for service sustainability", $12^{\text {th }}$ International Research Symposium on Service Excellence in Management, Ithaca, NY, June 2011.

Shirahada, K. and Fisk, R.P. (2013), "Service Sustainability: A Tripartite Value Co-Creation Perspective", in Kosaka, M. and Shirahada, K. (Eds.), Progressive trends in knowledge and system-based science for service innovation, IGI Global, Hershey, PA, pp. 89-99.

Strauss, A. and Corbin, J. (1990), Basics of qualitative research: Grounded theory procedures and techniques, Sage, London.

Vargo, S.L. and Lusch, R.F. (2004), "Evolving to a New Dominant Logic for Marketing", Journal of Marketing, Vol. 68 No. 1, pp. 1-17.

Vargo, S.L. and Lusch, R.F. (2011), "It's all B2B...and beyond: Toward a systems perspective of the market”, Industrial Marketing Management, Vol. 40 No. 2, pp. 181-187.

Van der Zwan, F. and Bhamra, T. (2003), "Services marketing: taking up the sustainable development challenge", Journal of Services Marketing, Vol. 17 No. 4, pp. 341-356.

Voss, C., Tsikriktsis, N. and Frohlich, M. (2002), "Case Research in Operations Management”, International Journal of Operations \& Production Management, Vol. 22 No. 2, pp. 195-219.

Wolfson, A., Tavor, D., Mark, S., Schermann, M. and Krcmar, H. (2010), "S3-sustainability and services science: Novel perspective and challenge", Service Science, Vol. 2 No. 4, pp. 216-224. 
Wolfson, A., Tavor, D. and Mark, S. (2011), "Better Place: A case study of the reciprocal relations between sustainability and service”, Service Science, Vol. 3 No. 2, pp. 172-181.

Wolfson, A., Tavor, D. and Mark, S. (2014), "CleanServs: Clean services for a more sustainable world", Sustainability Accounting, Management and Policy Journal, Vol. 5 No. 4, pp. 405-424.

Wong, C., Wong, C. and Boon-itt, S. (2013), "Green service practices: Performance implications and the role of environmental management systems", Service Science, Vol. 5 No. 1, pp. 69-84.

Yin, R.K. (2018), Case Study Research and Applications: Design and Methods, Sage, London, UK.

Zhang, J.J., Joglekar, N. and Verma, R. (2012), "Pushing the frontier of sustainable service operations management: Evidence from US hospitality", Journal of Service Management, Vol. 23 No. 3, pp. 377-399.

Zimmerman, E.W. (1951), World resources and industries: A functional appraisal of availability of agricultural and industrial resources, Harper, New York, NY. 
Table 1. An overview of research on green service.

\begin{tabular}{|c|c|c|c|c|}
\hline Authors & Study type & Concept & Definition & Resource integration processes \\
\hline $\begin{array}{l}\text { Gummesson } \\
(1993,1994)\end{array}$ & $\begin{array}{l}\text { Conceptual } \\
\text { with } \\
\text { illustrations }\end{array}$ & $\begin{array}{l}\text { Green service } \\
\text { management }\end{array}$ & $\begin{array}{l}\text { Managing the ecological and health impacts } \\
\text { of service organizations, as a part of their } \\
\text { business mission or strategy rather than a } \\
\text { reaction to legal or public policies. }\end{array}$ & $\begin{array}{l}\text { Recycling include reusing goods, repairing goods, } \\
\text { reconditioning/rebuilding goods, and recycling raw materials. }\end{array}$ \\
\hline $\begin{array}{l}\text { Grove et al. } \\
(1996)\end{array}$ & $\begin{array}{l}\text { Conceptual } \\
\text { with } \\
\text { illustrations }\end{array}$ & $\begin{array}{l}\text { Environmental } \\
\text { management }\end{array}$ & $\begin{array}{l}\text { Controlling the amount of natural resource } \\
\text { waste that often accompanies organizations' } \\
\text { marketing pursuits. }\end{array}$ & $\begin{array}{l}\text { The "three Rs" framework for resource management includes } \\
\text { reusing (packaging), recycling (materials), and reducing (resource } \\
\text { usage). }\end{array}$ \\
\hline $\begin{array}{l}\text { Bartolomeo } \\
\text { et al. (2003), } \\
\text { Cook (2014), } \\
\text { Heiskanen } \\
\text { and Jalas } \\
\text { (2003), } \\
\text { Johnson et } \\
\text { al. (1998), } \\
\text { Meijkamp } \\
\text { (1998), Mont } \\
\text { (2002), Roy } \\
\text { (2000), } \\
\text { Schrader } \\
\text { (1999), Van } \\
\text { der Zwan } \\
\text { and Bhamra } \\
\text { (2003) }\end{array}$ & $\begin{array}{l}\text { Single case } \\
\text { studies; } \\
\text { conceptual with } \\
\text { illustrations }\end{array}$ & $\begin{array}{l}\text { Eco-efficient } \\
\text { services } \\
\text { (EES), } \\
\text { product- } \\
\text { service } \\
\text { systems (PSS) }\end{array}$ & $\begin{array}{l}\text { EES are service-based market offerings that } \\
\text { reduce the ecological impact of fulfilling } \\
\text { customer needs (i.e. eco-efficiency) by } \\
\text { providing the utilization of goods (i.e. desired } \\
\text { functions or intended results) without } \\
\text { physical ownership (Bartolomeo et al. 2003, } \\
\text { Heiskanen and Jalas 2003, Meijkamp 1998, } \\
\text { Schrader 1999, Van der Zwan and Bhamra } \\
\text { 2003). PSS form a bundle of eco-designed } \\
\text { goods, EES, and supporting technology } \\
\text { networks that facilitate the dematerialization } \\
\text { of consumption by satisfying customer needs } \\
\text { by substituting product ownership with } \\
\text { service provision (Cook 2014, Mont 2002, } \\
\text { Roy 2000). }\end{array}$ & $\begin{array}{l}\text { Reducing usage of natural resources through product-based } \\
\text { services complementing product ownership through life-extension } \\
\text { services (e.g., maintenance, revalorization), as well as demand-side } \\
\text { management (e.g., reducing energy consumption by changing } \\
\text { customer behavior). } \\
\text { Reusing resources through use-oriented services substituting for } \\
\text { product ownership through pooling, renting, or leasing services } \\
\text { (e.g., car rentals, ridesharing) and result-oriented services offering } \\
\text { the benefits of product ownership, through intangible solutions, } \\
\text { electronic substitution and information-based services (e.g., } \\
\text { hairdresser, laundromat, energy system, advice and consultancy). }\end{array}$ \\
\hline $\begin{array}{l}\text { Graedel } \\
(2003)\end{array}$ & $\begin{array}{l}\text { Conceptual } \\
\text { with } \\
\text { illustrations }\end{array}$ & $\begin{array}{l}\text { Streamlined } \\
\text { life-cycle } \\
\text { assessment }\end{array}$ & $\begin{array}{l}\text { Evaluation technique to measure } \\
\text { environmental performance according to a } \\
5 \times 5 \text { assessment matrix: life-cycle stages of a } \\
\text { service vs. environmental concerns (energy } \\
\text { use, production process residues, habitat } \\
\text { disruption, material choice) }\end{array}$ & $\begin{array}{l}\text { Recommendations for "greening the service industries": designing } \\
\text { eco-efficient buildings, purchasing environmentally superior } \\
\text { products, selling services (the product's functions) instead of } \\
\text { product ownership. }\end{array}$ \\
\hline
\end{tabular}


Table 1. An overview of research on green service (continued).

\begin{tabular}{|c|c|c|c|c|}
\hline Authors & Study type & Concept & Definition & Resource integration processes \\
\hline $\begin{array}{l}\text { Enquist et al. } \\
\text { (2007), } \\
\text { Shirahada } \\
\text { and Fisk } \\
\text { (2011, 2013), } \\
\text { Wolfson et } \\
\text { al. (2010, } \\
2011,2014) \text {, }\end{array}$ & $\begin{array}{l}\text { Single case } \\
\text { studies; } \\
\text { conceptual with } \\
\text { illustrations }\end{array}$ & $\begin{array}{l}\text { Sustainable } \\
\text { service } \\
\text { (business), } \\
\text { service } \\
\text { sustainability }\end{array}$ & $\begin{array}{l}\text { Sustainable service systems adopt a triple- } \\
\text { bottom-line long-term approach to } \\
\text { environmental (e.g., emissions and pollution), } \\
\text { economic (inflation, unemployment, growth), } \\
\text { and social (income, education, health) } \\
\text { impacts of businesses and consumption. }\end{array}$ & $\begin{array}{l}\text { Smart and sustainable transportation (e.g. bulk retail, electric- } \\
\text { based vehicles), manufacturing from environmentally friendly } \\
\text { materials (including packaging), preventing or replacing } \\
\text { production (e.g., digital ticketing, e-books), and changing } \\
\text { consumer behavior (e.g., recycling) reduce natural resource } \\
\text { depletion. }\end{array}$ \\
\hline $\begin{array}{l}\text { Chan et al. } \\
\text { (2016), } \\
\text { Cocca and } \\
\text { Ganz (2015), } \\
\text { Hsiao et al. } \\
\text { (2018) } \\
\text { Isaksson and } \\
\text { Huge-Brodin } \\
\text { (2013), } \\
\text { Lacoste } \\
\text { (2016), } \\
\text { Wong et al. } \\
\text { (2013), } \\
\text { Zhang et al. } \\
\text { (2012) }\end{array}$ & $\begin{array}{l}\text { Multiple case } \\
\text { studies; } \\
\text { surveys; } \\
\text { panel data }\end{array}$ & $\begin{array}{l}\text { Green } \\
\text { logistics, } \\
\text { sustainable } \\
\text { operations } \\
\text { management }\end{array}$ & $\begin{array}{l}\text { Providing operational services (e.g., } \\
\text { transportation) that satisfy business } \\
\text { customers' and end-consumers' needs, while } \\
\text { reducing the environmental impact of service } \\
\text { provision by involving the network of } \\
\text { suppliers and customers in the co-delivery of } \\
\text { sustainable value. Through resource } \\
\text { efficiency in the supply chain (e.g., } \\
\text { combining transports modes, documenting } \\
\text { emissions and energy data), operational costs } \\
\text { are reduced and performance increased. }\end{array}$ & $\begin{array}{l}\text { To reduce waste (e.g., packaging, raw material), energy use, and } \\
\text { greenhouse gas emissions, resource efficiency is pursued (1) at the } \\
\text { core (i.e., full integration of sustainability principles as a strategic } \\
\text { orientation) of the service firm's operational management (e.g., } \\
\text { using eco-friendly fuel alternatives and eco-efficient vehicles, } \\
\text { redesigning products eco-efficiently, switching to online and } \\
\text { digital instead of paper-based processes, replacing products with } \\
\text { service provision); or (2) in support of other service firms in the } \\
\text { supply chain (e.g., combining transport modes, collecting } \\
\text { recyclable materials, energy consulting, maintenance services, } \\
\text { raising end-customers' awareness). }\end{array}$ \\
\hline $\begin{array}{l}\text { Chun and } \\
\text { Giebelhausen } \\
(2012) \text {, } \\
\text { Hsiao et al. } \\
\text { (2018), } \\
\text { Rosenbaum } \\
\text { and Wong } \\
\text { (2015), } \\
\text { Zhang et al. } \\
\text { (2012) }\end{array}$ & $\begin{array}{l}\text { Experiments; } \\
\text { surveys; } \\
\text { panel data }\end{array}$ & $\begin{array}{l}\text { Green } \\
\text { programs, } \\
\text { green } \\
\text { activities }\end{array}$ & $\begin{array}{l}\text { Firms in the hospitality sector (hotels) } \\
\text { committed to sustainability and concerned } \\
\text { about reducing the environmental impact of } \\
\text { their supply chain activities. }\end{array}$ & $\begin{array}{l}\text { Reducing the environmental impact of hospitality services involves } \\
\text { the end-consumers (e.g., influencing behavior, reminding them } \\
\text { about sustainability initiatives such as sorting out trash), but also } \\
\text { involves the service firm's activities (e.g., purchasing eco-efficient } \\
\text { products, technologies, and facilities; conserving electricity and } \\
\text { water resources with energy-efficient light bulbs, renewable } \\
\text { energy from solar panels, and reduced linen services; recycling; } \\
\text { training employees; replacing products with service provision; and } \\
\text { sourcing organically grown or local food). }\end{array}$ \\
\hline
\end{tabular}


Table 2. An overview of the case studies.

\begin{tabular}{|c|c|c|c|c|}
\hline Case & Description & Green service & Outcome & Description of data collection \\
\hline Valmet & $\begin{array}{l}\text { A manufacturer of eco- } \\
\text { efficient pulp and paper } \\
\text { machines }\end{array}$ & $\begin{array}{l}\text { New technology reducing water } \\
\text { consumption during machine } \\
\text { usage }\end{array}$ & $\begin{array}{l}\text { B2B customers use } 30 \\
\text { percent less water in } \\
\text { paper production }\end{array}$ & $\begin{array}{l}\text { Interviews with CEO, marketing manager, and service } \\
\text { manager, and site visits during 2015-2018 }\end{array}$ \\
\hline Volvo & $\begin{array}{l}\text { A manufacturer of } \\
\text { transportation vehicles }\end{array}$ & $\begin{array}{l}\text { "Eco-operator" driver training } \\
\text { reducing fuel consumption of } \\
\text { trucks, buses, and construction } \\
\text { equipment }\end{array}$ & $\begin{array}{l}\text { Drivers save } 20 \text { percent } \\
\text { fuel-reduced emissions }\end{array}$ & $\begin{array}{l}\text { Interviews with the service manager at Volvo Trucks. } \\
\text { Interviews with four marketing managers at Volvo } \\
\text { Construction Equipment, and two of their dealers. } \\
\text { Interviews with the service manager and the marketing } \\
\text { manager at Volvo Buses. }\end{array}$ \\
\hline $\begin{array}{l}\text { The Red } \\
\text { Cross }\end{array}$ & $\begin{array}{l}\text { Local thrift stores collecting } \\
\text { discarded products and } \\
\text { donations to resell them at } \\
\text { low prices since } 1991\end{array}$ & $\begin{array}{l}\text { Marketplace for second-hand } \\
\text { products }\end{array}$ & $\begin{array}{l}\text { A customer gets } \\
\text { ownership of used clothes } \\
\text { and materials }\end{array}$ & $\begin{array}{l}\text { Interviews, personal communication with the service } \\
\text { manager responsible for three stores, and site visits; } \\
2016-2017\end{array}$ \\
\hline Econova & $\begin{array}{l}\text { Organization creating } \\
\text { fertilizer from wood products } \\
\text { since } 1976\end{array}$ & $\begin{array}{l}\text { Renewable waste management } \\
\text { by collecting waste from pulp } \\
\text { mill to transform it into } \\
\text { fertilizer since } 2001\end{array}$ & $\begin{array}{l}\text { Consumers buy eco- } \\
\text { friendly fertilizer }\end{array}$ & $\begin{array}{l}\text { Interviews with two managers, three workshops, and site } \\
\text { visits; 2015-2017 }\end{array}$ \\
\hline $\begin{array}{l}\text { Tekniska } \\
\text { Verken }\end{array}$ & $\begin{array}{l}\text { Regional energy producer } \\
\text { since } 1902\end{array}$ & $\begin{array}{l}\text { Collecting household waste to } \\
\text { produce biogas since } 2012\end{array}$ & $\begin{array}{l}\text { Biogas accounts for } 6 \\
\text { percent of local fuel } \\
\text { consumption }\end{array}$ & $\begin{array}{l}\text { Interviews and three workshops with three managers; } \\
\text { 2015-2017 }\end{array}$ \\
\hline GoMore & $\begin{array}{l}\text { Shared mobility platform } \\
\text { facilitating private car rental } \\
\text { since } 2005\end{array}$ & $\begin{array}{l}\text { Reducing car ownership and } \\
\text { through P2P exchange of } \\
\text { products since } 2014\end{array}$ & $\begin{array}{l}\text { Increased usage of } \\
\text { underutilized tangible } \\
\text { resources (idling cars) }\end{array}$ & $\begin{array}{l}\text { Interviews with the CMO and three marketing managers; } \\
2015\end{array}$ \\
\hline Skjutsgruppen & $\begin{array}{l}\text { Non-profit civil society } \\
\text { organization facilitating } \\
\text { ridesharing since } 2007\end{array}$ & $\begin{array}{l}\text { Reducing car usage by } \\
\text { increasing shared resource } \\
\text { utilization }\end{array}$ & $\begin{array}{l}\text { Increased usage of } \\
\text { underutilized intangible } \\
\text { resources (empty space) }\end{array}$ & $\begin{array}{l}\text { Interviews and personal communication with the founder; } \\
2015-2017\end{array}$ \\
\hline
\end{tabular}


Table 2. An overview of the case studies (continued).

\begin{tabular}{|c|c|c|c|c|}
\hline Case & Description & Green service & Outcome & Description of data collection \\
\hline Dalhalla & $\begin{array}{l}\text { Former limestone quarry } \\
\text { turned into an outdoor } \\
\text { amphitheater in } 1993\end{array}$ & $\begin{array}{l}\text { Upcycling waste materials into } \\
\text { a new product }\end{array}$ & A servicescape for opera & $\begin{array}{l}\text { Interviews, personal communication with the founder, } \\
\text { workshops with the CEO and five shareholders, and site } \\
\text { visits; 2001-2017. }\end{array}$ \\
\hline MaxTech & $\begin{array}{l}\text { Creating and maintaining } \\
\text { lakes, rivers and other } \\
\text { wetland areas since } 2001\end{array}$ & $\begin{array}{l}\text { Creating new natural } \\
\text { environments }\end{array}$ & $\begin{array}{l}\text { New water ecosystems } \\
\text { are created }\end{array}$ & $\begin{array}{l}\text { Interviews and personal communication with the sales } \\
\text { manager and one customer; 2013-2017. }\end{array}$ \\
\hline Pratensis & $\begin{array}{l}\text { Landscaping flower meadows } \\
\text { since } 2005\end{array}$ & Creating new biodiversity & $\begin{array}{l}\text { New meadows and } \\
\text { plantations are created }\end{array}$ & $\begin{array}{l}\text { Interviews and personal communication with the CEO } \\
\text { and two customers; 2013-2017 }\end{array}$ \\
\hline
\end{tabular}


Table 3. Resource integration processes of green service.

\begin{tabular}{|c|c|c|c|c|c|}
\hline Process & Aim & Focal operand resources mobilized & Focal operant resources mobilized & $\begin{array}{l}\text { Strategic } \\
\text { operational } \\
\text { orientations }\end{array}$ & $\begin{array}{l}\text { Resource } \\
\text { integration } \\
\text { processes }\end{array}$ \\
\hline Reducing & $\begin{array}{l}\text { To alter the manufacturing of tangible } \\
\text { products and redesign service } \\
\text { processes to conserve resources }\end{array}$ & $\begin{array}{l}\text { Tangible manufactured products (e.g., } \\
\text { industrial machinery, vehicles) }\end{array}$ & $\begin{array}{l}\text { Technology, skills, or knowledge (e.g., } \\
\text { Valmet's OptiCycle technology, } \\
\text { Volvo's Eco-Operator training) }\end{array}$ & Support & Homopathic \\
\hline Recirculating & $\begin{array}{l}\text { To use existing tangible resources } \\
\text { again by changing their ownership and } \\
\text { extending their utilization }\end{array}$ & $\begin{array}{l}\text { Products no longer utilized (e.g., } \\
\text { discarded and refurbished items sold by } \\
\text { the Red Cross) }\end{array}$ & $\begin{array}{l}\text { Sustainability engagement is aligned } \\
\text { with the brand }\end{array}$ & Support & Homopathic \\
\hline Recycling & $\begin{array}{l}\text { To collect, reclaim, sort, and } \\
\text { demanufacture waste back into raw } \\
\text { material for industrial remanufacturing } \\
\text { instead of virgin resources }\end{array}$ & $\begin{array}{l}\text { Waste (un-resources), such as food } \\
\text { leftovers, or sludge }\end{array}$ & $\begin{array}{l}\text { Technology (e.g., Tekniska Verken's } \\
\text { biogas production technology, } \\
\text { Econova's industrial waste bio- } \\
\text { treatment processes) and end- } \\
\text { consumers (e.g., Tekniska Verken's } \\
\text { "green bag” program involving } \\
\text { household members sorting out waste) }\end{array}$ & Core & Homopathic \\
\hline Redistributing & $\begin{array}{l}\text { To enable the temporary circulation } \\
\text { and shared usage of under-utilized } \\
\text { resources (i.e., no permanent change in } \\
\text { ownership) }\end{array}$ & $\begin{array}{l}\text { Underutilized tangible (e.g., parked } \\
\text { cars) or intangible assets (e.g., space) }\end{array}$ & $\begin{array}{l}\text { Technology (e.g., collaborative } \\
\text { consumption platforms' matchmaking } \\
\text { algorithm) and end-consumers (e.g., } \\
\text { user base of aggregated supply and } \\
\text { demand for P2P services) }\end{array}$ & Support & Homopathic \\
\hline Reframing & To give waste a new purpose & $\begin{array}{l}\text { Tangible (e.g., limestone quarry) and } \\
\text { intangible waste (e.g., visual pollution) }\end{array}$ & $\begin{array}{l}\text { Knowledge (e.g., Dalhalla's acoustic } \\
\text { servicescape design) and creativity }\end{array}$ & Core & Heteropathic \\
\hline Renewing & $\begin{array}{l}\text { To create new natural ecosystems, } \\
\text { restore or replant depleted natural } \\
\text { resources, and improve or expand } \\
\text { existing natural resources }\end{array}$ & $\begin{array}{l}\text { Natural resources (e.g., seeds, water, } \\
\text { nutrient soil) and industrial machinery } \\
\text { (e.g., MaxTech's digger capturing } \\
\text { emissions) }\end{array}$ & $\begin{array}{l}\text { Knowledge or skills (e.g., Pratensis' } \\
\text { biodiversity experience, MaxTech's } \\
\text { landscaping skills) }\end{array}$ & Core & Heteropathic \\
\hline
\end{tabular}

